\title{
ADAT PERKAWINAN SUKU BUGIS DI KOTA JAMBI: STUDI TENTANG PERUBAHAN SOSIAL
}

\section{MARRIAGE CUSTOM BY BUGIS TRIBE IN JAMBI CITY: THE STUDY OF SOCIAL CHAGE}

\author{
Siti Syuhada, Apdelmi, dan Abd Rahman \\ Program Studi IImu Sejarah, Fakultas IImu Budaya Universitas Jambi \\ syuhadasiti2008@gmail.com, apdelmi1985@gmail.com, amanrasyid@yahoo.com
}

Naskah diterima: 25 Juni 2018; direvisi:15 Mei 2019; disetujui: 20 Juni 2019

\begin{abstract}
ABSTRAK
Masyarakat Bugis menganggap bahwa upacara perkawinan merupakan sesuatu hal yang sangat sakral, artinya mengandung nilai-nilai yang suci. Terdapat bagian-bagian tertentu pada rangkaian upacara tersebut yang bersifat tradisional. Dalam perkembangannya, masyarakat Bugis tidak hanya berdomisili di daerah Sulawesi saja akan tetapi telah menyebar ke berbagai wilayah Indonesia, salah satunya adalah di kota Jambi. Orang-orang Bugis membentuk komunitas tersendiri, dengan berbagai adat dan tradisi termasuk memelihara adat perkawinan yang masih berlaku sampai sekarang

Dalam acara perkawinan pada masyarakat Bugis yang ada di kota Jambi ada dua tahap dalam proses pelaksanaan upacara perkawinan masyarakat Bugis yaitu, tahap sebelum dan sesudah akad perkawinan. Dalam tradisi masyarakat Bugis, pengadaan pesta perkawinan sangatlah diharuskan. Hal itu berkaitan erat dengan status sosial mereka dalam masyarakat. Semakin meriah penyelenggaraan pesta perkawinan, semakin tinggi status sosial mereka di masyarakat. Hukum adat perkawinan mengatur aturan hukum adat yang mengatur tentang bentuk-bentuk perkawinan, cara-cara pelamaran, upacara perkawinan. Suku Bugis yang ada di kota Jambi sangat memperhatikan adat perkawinan dan dianggap dapat menaikkan status sosial di masyarakat terutama di kota Jambi sehingga dapat mempertahankan adat-istiadat suatu kelompok masyarakat agar terhindar dari kepunahan dan sebagai bukti mencintai serta menghargai adat perkawinan yang diperoleh dari daerah asal masyarakat suku Bugis yaitu dari Sulawesi Selatan.
\end{abstract}

Kata Kunci: Adat Perkawinan, Suku Bugis, Status Sosial.

Abstract

The Bugis community considers that a marriage ceremony is something that is very sacred, meaning it contains sacred values. There are certain parts of the series of ceremonies which are traditional in nature. In its development, the Bugis people did not only live in the Sulawesi region but have spread to various parts of Indonesia, one of which is in the city of Jambi. The Bugis people form their own community, with various customs and traditions including maintaining the customs of marriage that are still valid today

In a marriage ceremony for Bugis people in Jambi city there are two stages in the process of carrying out the marriage ceremony of the Bugis community, namely, the stages before and after the marriage contract. In the tradition of the Bugis people, procuring a wedding party is very necessary. It is closely related to their social status in society. The more festive the wedding party is, the higher their social status in the community. The customary law of marriage regulates the rules of customary law which regulate the forms of marriage, ways of applying, marriage ceremonies. The Bugis tribe in the city of Jambi is very concerned about marriage customs and is considered to be able to increase social status in the community, especially in the city of Jambi so as to maintain the customs of a community group to avoid extinction and as proof of love and respect for traditional customs obtained from the community. the Bugis tribe, namely from South Sulawesi. 
Keywords: Adat Marriage, Bugis Tribe, Social Status.

\section{PENDAHULUAN}

Seiring dengan perkembangan zaman, sentuhan tekhnologi modern telah mempengaruhi dan menyentuh masyarakat Bugis, namun kebiasaankebiasaan yang merupakan tradisi turun menurun bahkan yang telah menjadi Adat masih sukar untuk dihilangkan. Kebiasan-kebiasaan tersebut masih sering dilakukan meskipun dalam pelaksanaannya telah mengalami perubahan, namun nilainilai dan makna masih tetap terpelihara dalam setiap upacara tersebut. Ada dua tahap dalam proses pelaksanaan upacara perkawinan masyarakat Bugis yaitu, tahap sebelum dan sesudah akad perkawinan. Bagi masyarakat Sulawesi Selatan pada umumnya, masyarakat Bugis khususnya menganggap bahwa upacara perkawinan merupakan sesuatu hal yang sangat sakral, artinya mengandung nilai-nilai yang suci. Terdapat bagian-bagian tertentu pada rangkaian upacara tersebut yang bersifat tradisional. Dalam sebuah pantun Bugis (elong) dikatakan : Iyyana kuala sappo unganna panasae na belo kalukue. Yang artinya
Kuambil sebagai pagar diri dari rumah tangga ialah kejujuran dan kesucian. Dalam kalimat tersebut terkadung arti yang sangat penting dalam menjalankan suatu perkawinan.

Dalam perkembangannya, masyarakat Bugis tidak hanya berdomisili di daerah Sulawesi saja akan tetapi telah menyebar ke berbagai wilayah Indonesia, salah satunya adalah di Kota Jambi. Orang-orang Bugis membentuk komunitas tersendiri, dengan berbagai adat dan tradisi termasuk memelihara adat perkawinan yang masih berlaku sampai sekarang. Berdasarkan pengamatan langsung yang dilakukan oleh penulis bahwa dalam perkawinan masyarakat Bugis di Kota Jambi memiliki tahaptahap kegiatan sebelum acara akad nikah dan sesudah akad nikah. Dengan demikian terdapat proses yang panjang yaitu tahap sebelum dilangsungkan perkawinan dan setelah dilangsungkan perkawinan. Bagi masyarakat Bugis di Kota Jambi, perkawinan berarti siala atau saling mengambil satu sama lain, jadi perkawianan merupakan ikatan timbal balik. Walaupun mereka berasal dari strata sosial yang berbeda, setelah mereka menjadi suami istri mereka 
merupakan mitra. Selain itu, bagi masyarakat Bugis, perkawinan bukan saja penyatuan dua mempelai semata, akan tetapi merupakan suatu upacara penyatuan dan persekutuan dua keluarga besar yang biasanya telah memiliki hubngan sebelumnya dengan maksud mendekatkan atau mempereratnya (Mappasideppé mabélaé atau mendekatkan yang sudah jauh). Dengan demikian judul proposal yang diajukan dalam penelitian ini adalah" Adat Perkawinan Suku Bugis Di Kota Jambi (Studi Tentang Perubahan Sosial)".

\section{TINJAUAN PUSTAKA}

Adat dapat diartikan antara lain: (1) aturan yang lazim diturut atau dilakukan sejak dahulu kala; (2) cara yang sudah menjadi kebiasaan; (3) wujud gagasan kebudayaan yg terdiri atas nilai-nilai budaya, norma, hukum, dan aturan yang satu dengan lainnya berkaitan menjadi suatu sistem (http://kamusbahasaindonesia.org.).

Kata 'adat' dianggap hasil adopsi dari istilah bahasa Arab yaitu al- adah atau al-ma'ruf, yang dapat pula dialihbahasakan sebagai 'budaya'. Aladah secara etimologis berarti suatu yang dikenal dan terjadi secara berulang-ulang. Kata al-ma'ruf diartikan sebagai "sesuatu yang baik" sebab sesuatu yang terjadi secara berulang-ulang itu pada biasanya adalah sesuatu yang menjadi kebutuhan masyarakat.

Dalam hal pemaknaan, perkawinan bagi masyarakat Bugis sama halnya dengan perkawinan pada umumnya di daerah-daerah lain di Indonesia. Kerabat dekat dari kedua belah pihak juga selalu dilibatkan dalam setiap pelaksanaan upacara perkawinan adat Bugis. Namun, dalam tradisi masyarakat Bugis, pengadaan pesta perkawinan sangatlah diharuskan. Hal itu berkaitan erat dengan status sosial mereka dalam masyarakat. Semakin meriah penyelenggaraan pesta perkawinan, semakin tinggi status sosial mereka di masyarakat. Dalam adat Bugis sendiri, pelaksanaan pesta perkawinan umumnya diselenggarakan di rumah masing-masing kedua calon pengantin. Sedangkan upacara akad nikah biasanya dilakukan di rumah calon pengantin wanita. Namun, jika ingin menghemat biaya, maka pesta perkawinan hanya dilaksanakan di tempat orang tua calon pengantin wanita.

Adapun tahapan upacara perkawinan tersebut adalah sebagai berikut. 
1. Mappenre' Botting dan Madduppa Botting

2. Akad Nikah (Assimorong atau Menre' Kawing)

3. Mappasikarawa atau Mappasiluka (Persentuhan Pertama)

4. Marola atau Mapparola

Keterlibatan orang tua dan kerabat dalam pelaksanaan pesta perkawinan tidak dapat diabaikan. Mereka tetap memegang peranan sebagai penentu dan pelaksana dalam perkawinan anak-anaknya. Menurut Chabot (dalam Badruzzaman, 2007) mengatakan, pilihan pasangan hidup bukanlah urusan pribadi, namun merupakan urusan keluarga dan kerabat. Untuk itulah, perkawinan perlu dilakukan secara sungguhsungguh menurut agama dan adat yang berlaku di dalam masyarakat.

\section{METODE PENLITIAN}

Penelitian ini digolongkan dalam tipe penelitian diskriptif dengan analisis kualitatif artinya penelitian ini mengambarkan faktafakta tentang adat perkawinan suku Bugis di Kota Jambi. Pengumpulan data dilakukan dengan menggunakan teknik-teknik yaitu 1) Pengamatan yang dilakukan secara langsung untuk memperoleh gambaran tentang adat perkawinan suku Bugis mulai dari acara pra nikah sampai acara setelah akad nikah. Pengamatan dilakukan terhadap upacara perkawianan yang kebetulan dilakukan bersamaan dengan waktu penelitian, sehingga peneliti langsung mengamati upacara tersebut sekaligus mengetahui tentang perubahan-perubahan yang terjadi dalam upacara perkawinan tersebut; 2) Selain pengamatan pengumpulan data dilakukan dengan wawancara secara mendalam terhadap informan yaitu sebagai penghias pengantin suku Bugis (indobounting dibaca: indukboting) dalam acara perkawinan suku Bugis di Kota Jambi. Wawancara dilakukan, peneliti terlebih dahulu menjelaskan maksud dan tujuan dari penelitian dan hal-hal apa yang diperoleh dalam wawancara berkaitan dengan prosesi perkawinan adat suku Bugis di Kota Jambi serta nilai perubahan social yang terkandung di dalamnya. Pada saat wawancara, informan diberi kebebesan untuk mengemukakan pendapat tentang masalah yang diteliti sehingga dengan demikian wawancara dapat diharapkan dapat berjalan dengan teratur dan kemungkinan untuk memperoleh data yang objektif dan akurat lebih besar. 
Apabila terdapat kesulitan atau keraguan informan- informan dalam menjawab, maka informan diberi penjelasan tentang maksud dari pernyataan tersebut kemudian wawancara dilanjutkan.

\section{HASIL}

Masyarakat Bugis di Kota Jambi yang memiliki budaya khas dan unik dengan menggabungkan budaya Melayu setempat kebanyakan menganut agama Islam. Oleh sebab itu, pengaruh budaya Islam sangat terlihat pada kebudayaan Bugis ini di manapun mereka berada. Salah satu dari tiga pengetahuan utama yang dimanfaatkan oleh masyarakat Bugis untuk menempatkan diri pada hierarki masyarakat adalah pengetahuan tentang individu diperlakukan dalam ritual resmi khususnya pada acara perkawinan. Proses penyelenggaraan perkawinan masyarakat Bugis harus dipatuhi, mengingat hubungan intim antara laki-laki dan perempuan menurut masyarakat Bugis tanpa didahului dengan penyelenggaraan pesta perkawinan, dianggap sebagai perbuatan yang sangat memalukan (mappakasiri').

Konsep mapakasiri atau
disingkat dengan siri di atas

mencerminkan bahwa prinsip ini mempunyai arti tersendiri dengan nilai yang tinggi meliputi segala sisi kehidupan masyarakatnya secara keseluruhan di manapun mereka berada, setelah sekian lama merantau dan menetap di pelbagai wilayah, termasuk juga masyarakat Bugis yang ada di Kota Jambi. Prinsip ini kekal dipraktikkan sebagai adat, budaya dan prinsip. 'Siri' juga termasuk prinsip kebijakan dalam pemerintahan bersifat benar dan tepat, sebab dalam persoalan kenegaraan suatu pemerintah yang baik siri' mempunyai falsafah tersendiri, bahkan dijadikan sebagai pendorong untuk bertindak lebih hati-hati bagi siapa saja yang memegang pucuk kepemimpinan dalam masyarakatnya, demikian pula sebaliknya di mana masyarakat perlu memperlihatkan ketaatan kepada pemimpinnya, hal inilah yang telah dikenal lama oleh orang Bugis sejak zaman ke zaman.

Dari pelbagai ungkapan di atas, siri' atau menjunjung harga diri memberikan suatu petunjuk adat dan budaya mendalam yang melekat pada masayarakat Bugis bahkan menjadi satu kultur pandangan hidup mereka dengan menyangkut segala segi 
kehidupan mereka secara keseluruhannya. Selain siri' juga memegang peranan penting yang dapat berlaku atau diterapkan terhadap segala kehidupannya, sama ada mengarah kepada sesuatu yang baik maupun yang kurang baik. Tetapi pada prinsipnya penerapan siri' ini selalu diterjemahkan kepada kebaikan walaupun dampaknya adalah keburukan. Akibat rasa malu tersebut akan berujung pada beban moral yang dirasakan oleh anggota keluarga khususnya ketika ingin mengadakan acara pernikahan atau perkawinan adat suku Bugis yang ada di kota Jambi. Kemudian aplikasi mapakasiri salah satunya adalah menyelenggarakan adat perkawinan yang merupakan suatu institusi sosial yang sangat penting dalam adat istiadat masyarakat Bugis termasuk Bugis di kota Jambi. Bagi masyarakat Bugis hubungan intim antara lelaki dan perempuan tanpa didahului oleh penyelenggaraan majelis perkawinan adalah merupakan perbuatan yang tidak bermaruah, bahkan menjadi acara yang sangat memalukan (mappakasiri'-siri') kalau tidak disempurnakan dengan baik.

Menurut pandangan orang
Bugis, perkawinan tidak hanya menyatukan dua mempelai dalam hubungan suami-istri, tetapi perkawinan merupakan suatu upacara yang bertujuan untuk menyatukan dua keluarga besar yang telah terjalin sebelumnya menjadi semakin erat atau dalam istilah orang Bugis disebut mappasideppé mabélaé atau mendekatkan yang sudah jauh (Pelras, 2006). Seperti yang tergambar pada gambar berikut di bawah ini yang merupakan sebuah adat perkawinan dari suku bugis yang ada di kota Jambi yang dapat menyatukan dari kedua pihak keluarga baik mempelai laki-laki maupun perempuan.

\section{Gambar 1: Upacara penyelenggaraan perkawinan suku Bugis yang ada di kota Jambi}

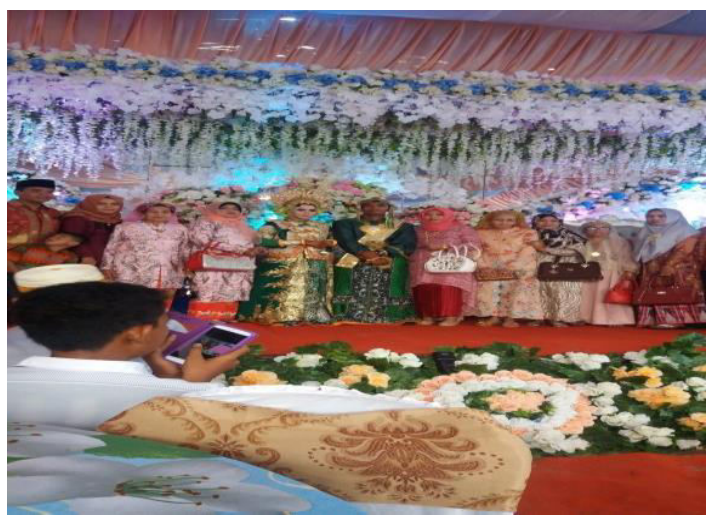

Berdasarkan gambar 1 di atas nampak terlihat dua keluarga atau dua pihak yang bertekad ingin mengikat secara 
kuat dalam ikatan perkawinan yang sah setelah menempuh berbagai tahap prosesi atau adat yang panjang mulai dari tahap sebalum dilangsungkannya adat dalam acara pernikahan sampai setelah selaesai acara pernikahan demi mencapai keluarga yang sakinah, mawadah dan warohmah.

Secara umum proses perkawinan suku Bugis terbagi atas dua tahapan, antara lain:

1. Upacara Sebelum Akad Perkawinan Setelah tercipta kesepakatan antara kedua pihak, kesibukan akan dimulai. Semakin tinggi status sosial dari keluarga yang akan mengadakan pesta perkawinan itu lebih lama juga dalam persiapan yang dilakukan. Untuk pelaksanan perkawinan dilakukan dengan menyampaikan bahwa akan ada pesta perkawinan kepada seluruh keluarga dan rekan-rekan. Hal ini dilakukan oleh beberapa orang perempuan dan laki-laki dengan menggunakan pakaian adat. Kegiatan ini dinamakan dengan mappaisseng. Tiga malam berturut-turut sebelum hari perkawinan calon pengantin mappasau (mandi uap), calon pengantin memakai bedak hitam yang terbuat dari beras ketan yang digoreng sampai hangus yang dicampur dengan asam jawa dan jeruk nipis. Setelah acara mappasau (mandi uap), calon pengantin dirias untuk upacara mappacci atau tudang penni. Acara wenni mappacci secara simbolik menggunakan daun pacci (pacar), dimana setelah acara ini berarti calon mempelai telah siap dengan hati yang suci bersih serta ikhlas untuk memasuki alam rumah tangga, dengan membersihkan segalanya, termasuk: mappaccing ati (bersih hati) , mappaccing nawa-nawa (bersih fikiran), mappaccing pangkaukeng (bersih/baik tingkah laku /perbuatan), mappaccing ateka (bersih itikat). Setelah pelaksanaan acara mappacci, maka dilanjutkan dengan akad nikah (kalau belum melakukan akad nikah). Pada masyarakat Bugis kadang melaksanakan akad nikah sebelum acara perkawinan dilangsungkan yang disebut istilah kawissoro. Kalau sudah melaksanakan kawissoro hanya diantar untuk melaksanakan acara mappasilukang dan makkarawa yang dipimpin oleh indo botting. Pada acara resepsi sebelum tamu datang, akan diadakan penyelenggaraan upacara khatam Al-Qur'an (mappanretemme). Pada acara resepsi juga akan ditampilkan acara hiburan (musik) untuk menghibur para tamu yang datang. 
2. Pertemuan resmi setelah perkawinan setelah pesta selesai, maka akan diadakan acara menginap tiga malam, dimana perempuan menginap di rumah laki-laki. Saat ini tiga malam masa menginap dipersingkat mejadi satu malam. Setelah acara ini selesai, maka dilanjutkan dengan siara kubur. Prosesi ini ditutup dengan acara massitabaiseng atau pertemuan antara mertua dengan mertua. Pada acara resepsi ada yang dinamakan dengan ana botting, hal ini dinilai mempunyai andil sehingga merupakan sesuatu yang tidak terpisahkan pada masyarakat Bugis di kota Jambi. Sebenarnya pada masyarakat Bugis, ana botting tidak dikenal dalam sejarah, dalam setiap perkawinan kedua mempelai diapit oleh balibotting dan passepik yang bertugas untuk mendampingi pengantin di pelaminan. Ana botting dalam perkawinan merupakan perilaku sosial yang mengandung nilai-nilai kemanusiaan dan merupakan ciri khas kebudayaan masyarakat Bugis pada umumnya dan orang Bugis pada khususnya, karena kebudayaan menunjuk kepada berbagai aspek kehidupan yang meliputi cara-cara berlaku, kepercayaan dan sikap-sikap serta hasil kegiatan manusia yang khas untuk suatu masyarakat satu kelompok penduduk tertentu.

Dalam proses perkawinan masyarakat Bugis yang ada di kota Jambi terdapat nilai yang terkandung dalam setiap prosesi, antara lain:

a. Nilai kekerabatan perkawinan merupakan satu wadah yang bisa mempererat

hubungan kekerabatan bukan hanya berfungsi sebagai penyatuan dua keluarga.

b. Status Sosial

c. Semakin meriah satu pesta maka semakin tinggi status sosial seseorang di masyarakat.

d. Penghargaan terhadap perempuan. Pemberian mahar (sompa) pada proses perkawinan suku Bugis di kota Jambi menunjukkan betapa mulianya seorang perempuan selain itu proses pelamaran menunjukkan penghormatan kepada perempuan di mana sebelumnya pihak laki-laki meminta restu kepada keluarga perempuan sebelum melakukan pesta perkawinan.

e. Gotong-royong pemberian bantuan berupa tenaga pikiran maupun dana menunjukkan adanya kepedulian 
antar sesama manusia.

\section{KESIMPULAN}

Dalam acara perkawinan pada masyarakat Bugis yang ada di kota Jambi ada dua tahap dalam proses pelaksanaan upacara perkawinan masyarakat Bugis yaitu, tahap sebelum dan sesudah akad perkawinan. Bagi masyarakat Sulawesi Selatan pada umumnya, dan masyarakat Bugis khususnya menganggap bahwa upacara perkawinan merupakan sesuatu hal yang sangat sakral, artinya mengandung nilai-nilai yang suci. Dalam upacara perkawinan adat masyarakat Bugis yang disebut "Appabottingeng ri Tana Ugi" terdiri atas beberapa tahap kegiatan. Kegiatan-kegiatan tersebut meliputi: 1. Mattiro (menjadi tamu); 2. Mapessek-pessek (mencari informasi); 3. Mammanuk- manuk (mencari calon); 4. Madduta mallino;

6. Mappasiarekkeng.

Dalam hal pemaknaan, perkawinan bagi masyarakat Bugis sama halnya dengan perkawinan pada umumnya di daerah-daerah lain di Indonesia. Kerabat dekat dari kedua belah pihak juga selalu dilibatkan dalam setiap pelaksanaan upacara perkawinan adat Bugis. Namun, dalam tradisi masyarakat Bugis, pengadaan pesta perkawinan sangatlah diharuskan. Hal itu berkaitan erat dengan status sosial mereka dalam masyarakat. Semakin meriah penyelenggaraan pesta perkawinan, semakin tinggi status sosial mereka di masyarakat. Hukum adat perkawinan adalah aturan-aturan hukum adat yang mengatur tentang bentuk-bentuk perkawinan, cara-cara pelamaran, upacara perkawinan dan alasan lain orang Bugis harus mengadakan pesta perkawinan adalah karena hal tersebut sangat

berkaitan dengan status sosial mereka dalam masyarakat. Adat istiadat merupakan sesuatu hal yang sangat berharga dalam suatu kelompok masyarakat, olehnya itu penulis menyarankan agar setiap masyarakat mempertahankan, menjaga dan memelihara adat istiadat tersebut agar tetap ada sampai kapanpun terutama bagi suku Bugis yang ada di kota Jambi. Karena suku Bugis mempunyai adat pernikahan yang sangat unik dan sangat kompleks, maka masyarakat Bugis khususnya dan masyarakat di Indonesia umumnya harus bangga dan menjaga 
adat istiadat tersebut supaya tidak punah.

\section{DAFTAR PUSTAKA}

Artikel yang berjudul “

Keanekaragaman Budaya

Tradisional", di akses di http://p2x1637winlie.blogs pot.com/2013/04/budayaindonesia-.html?m=1,pada tanggal 10 September, pada pukul 21.00 WIB.

Artikel yang berjudul, “ Belajar Hukum / Arti Perkawinan menurut UU No.1 tahun 1974 dan menurut KUH Perdata/BW,di akses di http://belajar-hukum- blog.blogspot.com/2011/08/artiperkawinan-menurut-UUNo1- tahun.html?m=1, pada tanggal 10 April 2018, pada pukul 02.19 WIB.

Hamid, Ismail. 1985. Peradaban Melayu dan Islam. Kuala Lumpur:

Fajar

Hilman Hadikusuma. 2013. Pengantar Ilmu Hukum Adat Indonesia. Bandung: Mandar Maju.

Kamus Besar Bahasa Indonesia. 1988. Jakarta: Departemen Pendidikan dan Kebudayaan Republik Indonesia.

Pelras, Christian. 2006. Manusia Bugis. Jakarta: Nalar

Tang, Mahmud. 2003. Solusi konflik dalam La Galigo dalam La Galigo Menelusuri Jejak Sastra Dunia. Makassar: Pusat Studi La Galigo Divisi
Ilmu Sosial dan Humainora

Pusat Kegiatan Penelitian Universitas Hasanuddin. 